\title{
An Overview of the Principles of the Teaching of Listening in EFL Class
}

\author{
Yongheng Wang \\ School of Foreign Languages, SWUN. Chengdu 610225, China \\ 1532698155@qq.com
}

Keywords: principles, learners, teacing listening, EFL Class.

\begin{abstract}
Listening is one of the four fundamental skills in any language and it is the most widely used language skill in conjunction with other skills of speaking, reading, and writing. But regrettably, the teaching of listening has been neglected for a long time in China. Fortunately, changes have been taking place in recent years and listening has been giving the same balanced weight now. This paper is aimed to provide an overview of the principles for the teaching of listening.
\end{abstract}

\section{Introduction}

Listening is not only as a way of exercising language skills, it is also an important means of getting information or interacting with others. In Brown and Yule's words, listening is interactional and transactional. 'Interactional talk' is used to refer to speech that is primarily social while the main purpose of 'transactional communication' is to achieve a successful transfer or exchange of information [1]. So, one of teachers' aims in teaching listening should be training students to listen with purposes and expectations. After establishing the purpose for listening, students will listen more carefully and thus, listen more successfully because they can listen selectively without the burden of remembering every detail they hear. In the process of teaching, the following principles of teaching listening should be always kept in mind.

\section{Principles of Teaching Listening}

\subsection{Principle 1.}

The first princile for the teaching of listening should be choosing appropriate materials for students according to their different levels and their different needs. There are various kinds of listening materials for us to use: videotapes, film, BBC news, songs, recorded tapes and even 'live' materials. Tape-recorded material is mostly used in the classroom in China and it may continue to be the most predominant type of materials used in China. Teachers like to use recorded material is because it can be replayed again and again and will always be the same. It is also easy for teachers to prepare the listening activity well before they arrive at the class. But teachers must listen to the material themsleves before they bring it to the classroom, because teachers need to know where the students might encounter with problesm and when they need to pause and explain. Besides, Underwood [2] says without seeing the speaker while listening means that students must concentrate on what they hear, instead of depending on the paralinguistic signals to guess the meaning of what is said.

But in my own teaching experience, I find only using recorded material can't satisfy students' needs and can't retain their interest for long in learning. In face, teachers can consciously provide students as much genuine communicative input as possible in class, which can provide students with useful listening practice. This kind of input can be called 'live' presentations. This is a very good means for students to practice listening: speakers can be seen, and so the listeners have all the non-verbal clues avaiable to help them decipher or guess the message with the help of facial expressions, the gestures, the movement of the head/body[3]. Using live presentations as listening materials, teachers can adjust the levels of difficulty easily, they can simplify and slow down a little to suit their students' level. 
Almost every English learner has following experience when they arrives in a foreign country on a first visit:he is unable to undertand what is being said to him although he has been learning English for so many years. Both 'live' presentations and tape recorded materials provided in the classroom do not seem to have adequate preparation for the real thing because neither of them can provide students how native English speakers speak in real life.

Therefore, it is now generally accepted that students need to practice listening to the kind of speech they will actually encounter in real life then they will be able to understand and respond to what English speakers are saying. This kind of speech is called 'authentic' speech which is defined by David Forman[4]) as: "any text is 'authentic' if it was produced in response to real life communicative needs rather than as an imitation of real life communicative needs". Authentic materials can give students the chance to hear a more real act of communication with all the international features which are normally not found in 'live' presentations or tape recorded materials used in the classroom in China. Mary Underwood summarizes the merits of authentic speech and she says authentic speech can give students a true representation of real, spontaneous speech with its hesitation, false starts and 'mistakes', which will make them more able to cope with 'real life' speech when they meet it outside the learning situation. If students have the opportunity to listen to a range of authentic texts, they will be exposed to many different voices, with varying accents, both social and regional, which are beneficial for them to communicate successfully in the future with a wide range of people from different countries.

Although authentic materials seem to be the best materials for English learners to use, many English teachers in China are not willing to use them in class because authentic materials are too difficult, even for some of the teachers. It is not easy for teachers to grade the levels of difficulty, and it is also hard for them to find precisely the right text to match the levle of their coursebook. With all these problesm it doesn't mean that we shoud not use authentic materials until our students have become advanced learners to begin using authentic materials but it means that as English teachers, we should spend some extra time and carefully select authentic materials that are appropriate for our students at different levels.

\subsection{Principle 2.}

The second princile of the teaching of listening in my point of view is how to plan tasks, exercises or activities appropriate to students. When designing listening exercises, we should take into account the following factors. FirsT, keep in mind the kind of real-life situation for which we are preparing students, and also the specific difficulties they might encounter and need pracitce to overcome[5]. Second, we should plan exercises or activities according to the nature of the classroom, for example, the size of the classroom, the number of students or the availability of the equipment. Third, the most important one, try to raise students' interest and motivate them. The following are the tways that can make the third goal become true:

Design task-oriented exercises to engage students interest and help them learn listening skills subconsciously. As Ur[6] has said, "listening exercises are most effective if they are constructed round a task. That is to say, the students are required to do something in response to what they hear that will demonstrate their understanding." She has suggested some such tasks: expressing agreement or disagreement, taking notes, making a picture of diagram according to instructions, and answering questions. Compared with traditional multiple-choice questions, task-based exercises have an obvious advantage. They can not only test students' listening comprehension but also encourage them to use different kinds of listening skills and strategies to reach their destinatin in an active way.

Provide students with easy tasks before moving to the more complex ones. Learners' motivation is a crucial factor for successful learning, so if a listener has experienced success in easy tasks, he or she possibly will have more self-confidence to practice other skills. In contrast, learners who are given tasks that are too difficuly to be comprehensible will be demotivated by lack of success in the tasks. The failure in the tasks may even lead to the formation of one of the passive and unsuccessful listening habits where the listeners equate 'listening' with sitting back and letting a largely meaningless sequence of sounds wash over them. The choice of the topics should not be too difficult or abatract either. 
Give students the pre-task and while-task support. Anderson and Lynch's [7] experimental results suggest that, if the listeners are specifically told in advance which features of the ensuring message are relevant to their listening purpose, the task is likely to be much easier. Therefore, if teachers give students adequate pre-listening support, students can attedn selectively to the appropriate parts of the message and thus decrease the amount of information processing and memorization involved. The pre-listening support given to students can enable learners to achieve a high level of sucess and thus become more confident. The pre-listening support includes a range of activities[8] :

The teacher giving background information;

The students reading something relevent;

The students looking at pictures;

Discussion of the topic/situation;

A question and answer session;

Written exercises;

Following the instructions for the while-listening activity;

Consideration of how the while-listening activity will be done.

While-listening activities are purposed to help students develop the skill of eliciting message from spoken language. Teachers can use while-listening activities to give students the chance to practise their ability of prediction, matching and interpretation that they have when listening in their own languages. Good while-listening activities can help students find their way through the listening text and build upon the expectations raised by pre-listening activities, but they should be interesting and they should be things that most students can do because the failure of the task will lead to demotivation.

\subsection{Principle 3.}

The third principle of teaching listening in EFL class is to help students establish a good habit: don't worry about the exact word or phrase they miss when they are listening. Many foreign-language learners have such a problem that they want ot understand everything, even those are totally unimportant. If they fail to understand a particular word or phrase, they will feel worried and thus become discouraged by their lack of success. Good teachers should let students know that a good language learner should be the one who can tolerate vagueness and incompleteness of knowledge because it is unnecessary or sometimes impossible for learners to understand very word, even for native speakers. What teachers need to do is encourage students to gather what they can from the information they can readily decode, and use their common sense and the strategy of making inferences to help them understand the whole. This kind of listening habit can help students feel at ease when they are listening, which is helpful for successful listening.

\section{Conclusion}

Most foreing language learners feel that listening skills is the most difficult skill to improve. As responsive English teachers, we must try our best to find out all we can about how listening can be improved and what kinds of materials and activities are helpful to this end and then put them into practice in our classroom. It is true that finding the best ways for our students to improve their listening skills at different levels is a hard and time-consuming task for teachers to do, so all the English teachers should work together to make this common goal become true in the near future.

\section{References}

[1]. Brown, G. and G.Yule. Teaching the Spoken Language. Cambridge: CUP. P.38

[2]. Underwood, M. Teaching Listening. New York: Longman Limited.1997. P11

[3]. Rost, M. Listening in Language Learning. London\&NY. 1997.P95

[4]. Underwood, M. Teaching Listening. New York: Longman Limited.19987. P97 
[5]. Brown, G. Listening to Spoken English. Essex: Longman.P24

[6]. Penny Ur. Teaching Listening Comprehension. Cambridge: CUP.1997 P25, P31

[7]. Anderson\&Lynch. Listening. Oxford: OUP. 2000. P.124

[8]. Penny Ur. Teaching Listening Comprehension. Cambridge: CUP.1997 P31 